\title{
The big NZ journalism survey: \\ Underpaid, under-trained, under-resourced, unsure about the future - but still idealistic
}

\section{IABSILACII}

This survey $(n=514)$ updates and extends previous surveys of New Zealand journalists, by measuring attitudes to resourcing, news coverage, ethics and standards, changing technology, ownership and other topics. Reasonably broad coverage of print, broadcast and internet journalists was achieved. Low pay and a lack of support and training, rather than staff numbers, were the standout concerns. Most respondents believed coverage of local, political, business and features was good, while sports achieved the highest rating and foreign coverage the lowest. Respondents generally rated ethics and standards as important, and while they had concerns about sensationalism, they did not seek more regulation. They considered the media was generally performing its watchdog role well, but had concerns about the impact of decreasing resources (especially staff numbers, levels of experience, and time to develop in-depth investigations) on that watchdog role, as well as the impact of changing technology, commercial and advertising pressures. They were evenly divided between antagonism and tolerance in their stances towards public relations. Respondents' political views were generally neutral or slightly left. There were significant differences across gender, job status, employer and age in many of the results. Demographic data suggest the workforce is becoming more feminised, (as earlier surveys have suggested), with disproportionate numbers of younger women and older men, and an apparent pay disparity between males and females.

\section{JAMES HOLLINGS, GEOFF LEALAND, ALAN SAMSON and ELSPETH TILLEY \\ Massey University and Waikato University}




\section{Introduction}

7 HIS survey updates and extends previous surveys (Lealand 1994, 1998, 2004; JTO 2006) on the age, income and other demographic

1 characteristics. It is also the first attempt to survey attitudes of New Zealand journalists in respect of resourcing, coverage and ethics. In addition, it explores factors of political orientation; questions which have never been asked before of journalists in this country.

This survey occurs at a time when the news media is undergoing rapid change, and facing numerous pressures from changing consumer preferences, shifts in advertising revenue, changes in ownership and technology. It is both timely and important to explore journalists' perceptions of the impact of these changes.

While much has been written about the possible or perceived impact of these trends, there is little or no reliable data on what journalists themselves think and feel about the state of their profession and industry. In addition, the generally low esteem in which they are held by the public is worthy of exploration: are they as unethical, politically biased, susceptible to commercial pressure, prone to plagiarism or fabrication, as the rankings of journalists in polls of public regard of the professions suggest? How do they see themselves? Do they believe they try to report things fairly? Do they believe there is a free press in New Zealand? What impact is changing technology having on their industry? How do journalists' perceptions of the impact of these trends vary between broadcast and print, or national and regional news media?

It is hoped that the data reported here will give journalists and the wider public a window into a profession which has the freedom to comment on all facets of human life, but much less often reflects upon its own values and practices. It may also provide insights into how to meet calls for under-represented groups to build senior role models in the newsroom, for example expanding the role of women beyond merely the junior ranks (Strong \& Hannis, 2007).

\section{Methodology}

\section{The questionnaire}

The questionnaire was drawn up using questions from previous surveys, some from the US Pew Survey (2004), and some nominated by the researchers involved in this project. The survey was piloted on a small group of journalists $(n=12)$ and the results used to identify the most useful questions for a broad questionnaire.

176 PACIFIC JOURNALISM REVIEW 13 (2) 2007 


\section{Sampling frame}

A distribution list of print, broadcast and internet news organisations was drawn up from published media guides, the researchers' industry knowledge, and media associations. Key people at each - mostly chief reporters or editors - were identified, sent an email directing them to an online questionnaire at an established commercial provider (Surveymonkey), and invited to forward the email to staff within their organisation. Follow-up phone calls at one day and one week later were made to ask if the email had been received and passed on. Survey responses were monitored as they arrived and areas with low response rates were prompted with follow-up calls and attempts to target respondents from these groups.

\section{The representativeness of participants}

Respondents were self-selecting and thus this survey cannot be considered random, and subject to conventional tests of probability and reliability, and thus cannot be regarded as truly representative of all New Zealand journalists. Nevertheless, a comparison of basic demographic characteristics by Hollings (2007) of national census data suggests that this particular survey also encompasses a similar profile group ${ }^{1}$, though with a response bias in some areas. For example, women made up 70 percent of full-time reporters $(n=185)$, half of subeditors $(n=23)$, but only 40 percent of managers $(n=55)$, despite making up 55 percent of all journalists in this survey. This differs from the 2006 Census, where although the overall male/female split was the same, the reporter split was 50-50, and the subeditor split 40/60 in favour of females (Statistics New Zealand, 2007).

The numbers participating in this 2007 survey are considerable, and more substantial than earlier surveys of New Zealand journalists (for example, Lealand, 2003, $n=297$ ). However, it is true that other surveys have featured greater returns, such as the 1994 Lealand survey $(n=1214)$ and the 2006 survey by the New Zealand Journalists Training Organisation, the formal body for journalism training $(n=1216)$. A possible explanation for this variability in returns are that this survey followed in the wake of the JTO's.

Given the general history of surveys of journalism in New Zealand, we nevertheless, we do take cognizance of John Henningham's (1995, p. 298) recommendation that alternative research methods should be explored-namely, a combination of targeted sampling and telephone interviewing. 

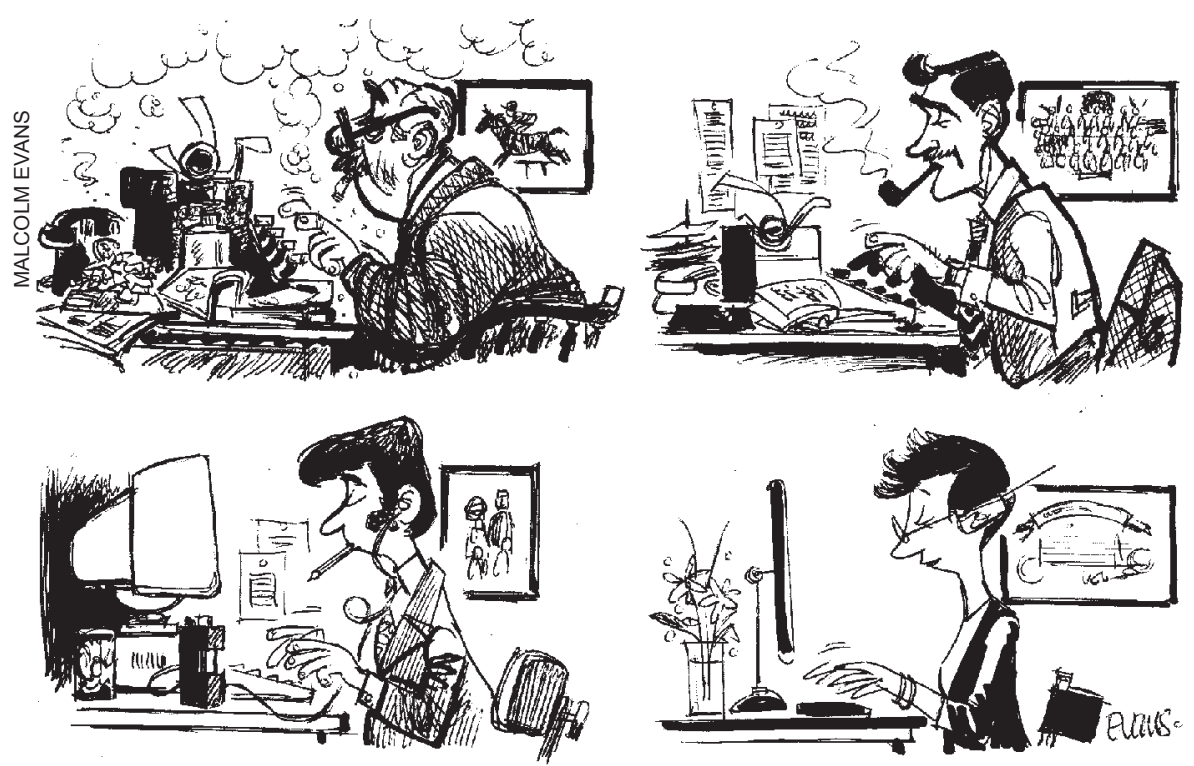

The evolving journalist: 'Young, European, female and new to journalism.'

These recommendations should be seriously considered in respect of any future research.

But we also want to avoid being too apologetic about our numbers. Surveys of journalists in other countries have regularly used small samples, to extrapolate to much larger populations. In their 1992 survey of American journalists, Weaver and Wilhoit drew on the experiences of 1410 workers in the print and electronic media, while the Pew Research Centre's 'The State of the News Media 2006' report based its conclusions on the responses of 547 national and local journalists. ${ }^{2}$

We would also argue that results provided here would most likely echo the general tendencies and gender/age/income 'skews' found in other professions, such as tertiary education, business and medicine. Our intention has been to gather and record the experiences and opinions of a wide range of New Zealand journalists and we feel reasonably confident that we have not distorted nor misrepresented the profession.

\section{The participants}

A reasonably good response rate $(n=514)$ of the 4000 estimated NZ journalists (Census, 2006) was achieved (see Table 1), with a fairly even spread 178 PACIFIC JOURNALISM REVIEW 13 (2) 2007 


\begin{tabular}{|c|c|c|c|c|c|c|c|c|}
\hline \multicolumn{2}{|l|}{ Gender } & \multicolumn{4}{|c|}{ Male } & \multicolumn{3}{|c|}{ Female } \\
\hline \multicolumn{2}{|l|}{ Percentage } & \multicolumn{4}{|c|}{43} & \multicolumn{3}{|c|}{57} \\
\hline \multicolumn{2}{|l|}{ Count } & \multicolumn{4}{|c|}{211} & \multicolumn{3}{|c|}{283} \\
\hline \multicolumn{2}{|l|}{ Age-years } & $<30$ & \multicolumn{2}{|c|}{$<40$} & $<45$ & \multicolumn{2}{|c|}{$<50$} & Median (4) \\
\hline \multicolumn{2}{|l|}{ Percentage } & 27 & \multicolumn{2}{|c|}{53} & 65 & \multicolumn{2}{|c|}{75} & 39 \\
\hline Count & & 138 & \multicolumn{2}{|c|}{270} & 332 & \multicolumn{2}{|c|}{396} & \\
\hline Qualification & \multicolumn{3}{|c|}{ None } & \multicolumn{3}{|c|}{ Diploma } & \multicolumn{2}{|c|}{$\begin{array}{l}\text { Degree or post- } \\
\text { grad qualification }\end{array}$} \\
\hline Percentage & \multicolumn{3}{|l|}{31} & \multicolumn{3}{|l|}{29} & \multicolumn{2}{|l|}{39} \\
\hline \multicolumn{2}{|l|}{ Count } & \multicolumn{2}{|c|}{162} & 146 & & & 197 & \\
\hline Ethnicity & Europear & & aori & & & & & Other \\
\hline Percentage & 86 & & & 0.6 & & 0 & & 8 \\
\hline Count & 444 & & & 3 & & 3 & & 41 \\
\hline Experience & $<1$ year & & & $6-10$ & & & $16-2$ & $21+$ \\
\hline Percentage & 7 & & & 16 & & & 10 & 29 \\
\hline Count & 35 & & & 81 & & & 49 & 144 \\
\hline Income & $<\$ 40,000$ & & 47,000 & $<\$ C$ & & & 0,000 & $>\$ 90,000$ \\
\hline Percentage & 22 & & 50 & & & & 5 & 11 \\
\hline Count & 148 & & 220 & & & & 21 & 47 \\
\hline
\end{tabular}




\section{Graph 1: Younger women, older men: male/female ratio in each age group}

Younger women, older men: Male/ female ratio in each age group

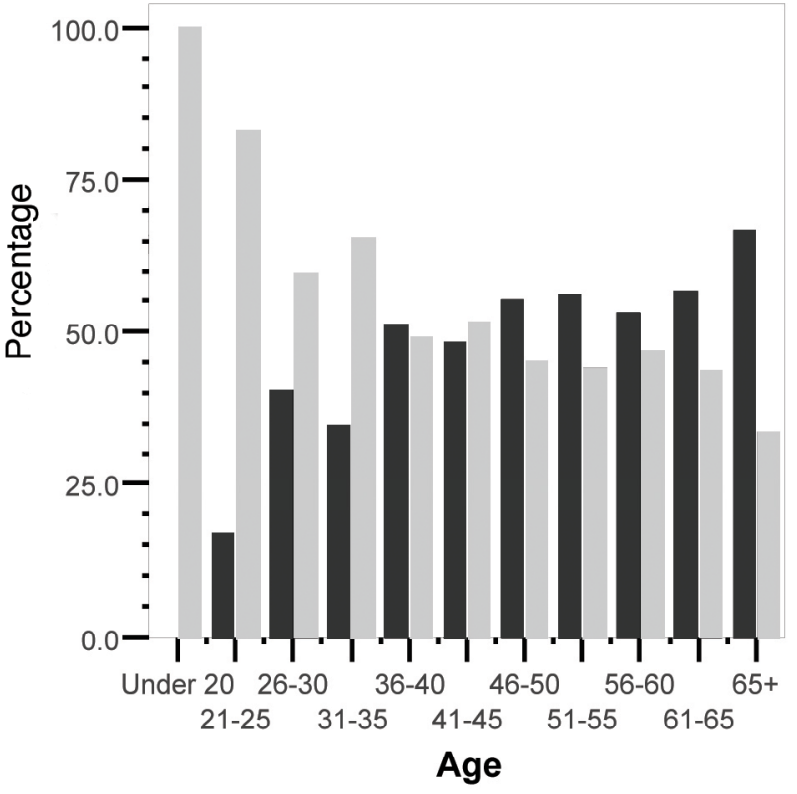

across media, though numbers in some niche categories such as news agencies, were predictably low. Data analysis ${ }^{3}$ show half the respondents are under 40 years, have less than 10 years experience, and earn under $\$ 50,000$ a year. More than half are female, and more than two thirds have a qualification.

Given the trends in the data above, and notwithstanding the need for caution about extrapolating from a self-selecting sample indicated above, we can construct a profile of the 'typical' New Zealand journalist in 2007. The primary characteristics are:
- young
- $\quad$ European (Pakeha)
- female
- formally educated 
- $\quad$ on a mid-range salary

- relatively new to journalism

This profile (keeping in mind that there is also considerable variation), does not contradict the findings of the two preceding surveys (Lealand, 2003; NZJTO, 2006), which also showed similar trends in respect of age, gender, income, ethnicity and experience.

\section{Results and discussion}

Gender, age, job and income

As shown in Graph 1, women greatly outnumber men in age groups up to about 35 years, then are progressively outnumbered after that. Over half of women respondents were under 35 years of age, and nearly two thirds under 40 years. Male respondents were much more likely to be earning more than women $(t=-8, d f=3.1, p<.001)$. However this was without controlling for age, experience or tenure, which was beyond the scope of the survey design. In fact, it is possible this disparity may be partly explained by the higher proportion of younger women and older men in this sample. A Chi-Square test found no significant difference between male and female income in the under-30 age group. Further research on the reasons for and effects of the overall disparity would be useful, and to see if it holds true for all journalists. Predictably, there was a significant difference in pay by job $(F=72, d f=2$, $387, p<.001)$. Managers earned more than reporters and subeditors. The effect size, calculated using eta squared, was 0.26 . A post-hoc comparison using the Tukey HSD test indicated that the mean score for managers $(M=6.1$, $S D=1.6)$ was significantly different from reporters $(M=3.8, S D=1.75)$ and subeditors $(M=4.5, S D=1.75)$. Likewise, pay varied significantly according to employer $(F=7.8, d f=6,363, p<.001)$, with TV journalists earning most, followed by newspaper national weeklies, national magazines, newspaper national dailies, regional daily newspapers, radio, then regional weekly newspapers.

\section{Experience}

Subeditors were most experienced, followed by those working in management, then photographers then reporters. Of the 266 full-time reporters, half had less than five years experience, a quarter 15 years or more, and the rest 5-15 years. Perhaps of some concern is that almost a fifth had more than 21 or more years experience, meaning they could be nearing the end of their 


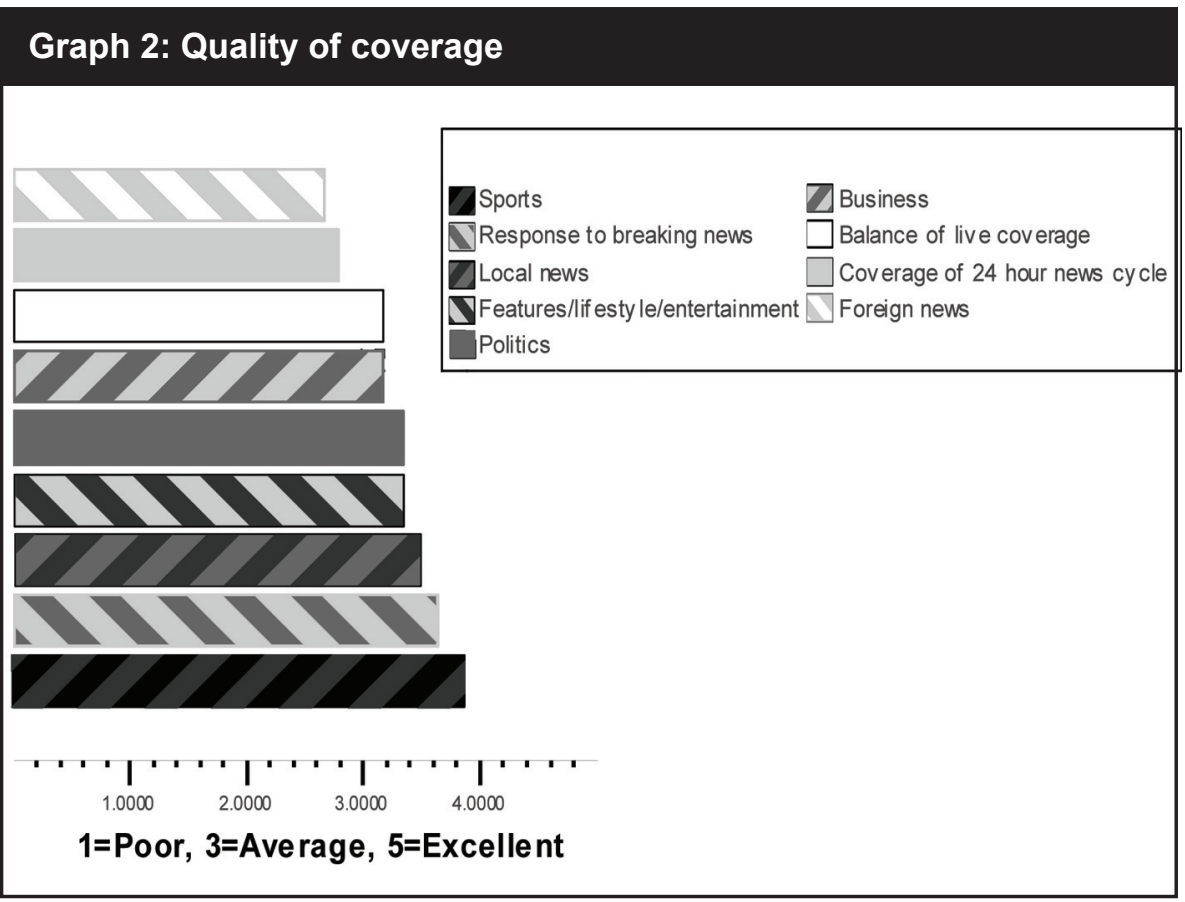

working career. Combined with the high proportion of relatively inexperienced reporters, this suggests the industry could be facing a serious shortage of those with mid-range experience in a few years. This is even more the case for subeditors, with half having more than 21 years experience. Almost half of those in management had less than 15 years experience.

\section{News coverage}

Most respondents believed the New Zealand media provides average or better coverage of the topics covered (Graph 2). All but two areas returned average or better scores, with sports coverage earning the highest rating, with almost 70 percent rating it above average or excellent. Of course, this result does not identify what kind of sports coverage is being judged here. Local and political coverage also scored highly. Coverage of foreign news and of the 24-hour news cycle was considered worse, at slightly below average. Women journalists rated the quality of political, business, sports and feature/entertainment coverage significantly higher than their male 
counterparts. (Political, male $M=3.2, S D=0.81$, female $M=3.42, S D=0.79$. eta $^{2}=.018, \mathrm{t}=2.8, p<.005$; business $\mathrm{eta}^{2}=.017$, sports $\mathrm{eta}^{2}=.02$, features $\mathrm{eta}^{2}=.002$ ). There were no significant differences of opinion between management, reporters and subeditors, with the exception of balance of live coverage $(F=4.4, d f=2,385, p<.05)$ where subeditors rated it below average, and all others above average (eta=0.02). There were no significant differences by age. There were significant differences by employer $(F=4, d f=6$, $370, p<.001)$ for local news, between radio and regional daily newspapers ( $e t a=0.06$ ), suggesting that journalists on regional dailies are more confident about the quality of local coverage than their national broadcasting counterparts. Overall, these results tend to confirm the commonly held view that the New 7ealand media is light on foreign coverage, while dominated by sports coverage and commentary.

\section{Resourcing}

As Graph 3 shows, this was clearly an area of concern for respondents, with all areas scoring below average. Pay was the biggest concern, followed respectively by lack of counselling and support, lack of mentoring/training, numbers of reporters, and numbers of senior staff. However, there was significant variation between groups over pay $(F=11.1, d f=2,389, p<0.001)$. Reporters were much more concerned than managers (eta $=0.05)$.

Surprisingly, all groups - including managers-were more concerned about pay, counselling and support, and lack of mentoring, than numbers of staff, even in their own group. For reporters, the biggest concern was pay, followed by counselling/support, mentoring/training, and then numbers of reporting and senior staff. However, reporters thought all resourcing areas were below average. Subeditors had similar, but generally lower scores, with the exception of the numbers of senior staff, which they rated better than average. For managers, pay, counselling, support and training were also the biggest concerns, but they were less concerned about staff levels. The only significant difference between older and younger journalists on resourcing was over pay, where there was a steady increase in satisfaction as age increased $(F=4.3, d f=10, p<.001)$, although all groups still scored pay below average. It is clear that those in the 20-30 year age group are very unhappy about pay levels. Those in the 21-25 year age group rated it lowest, with a mean score of 1.4 , the lowest of any in this survey. When analysed by employer, there 


\section{Graph 3: Resourcing}
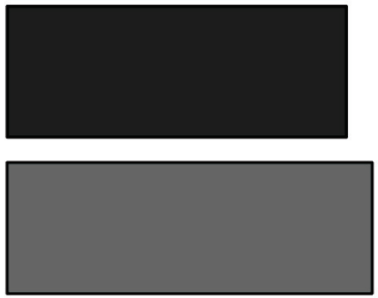

$\square$ Numbers of senior staff

$\square$ Numbers of reporters

$\square$ Mentoring/training

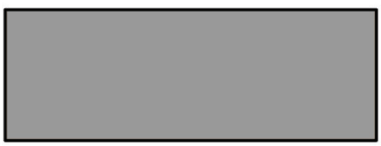

$\square$ Counselling/support

Pay
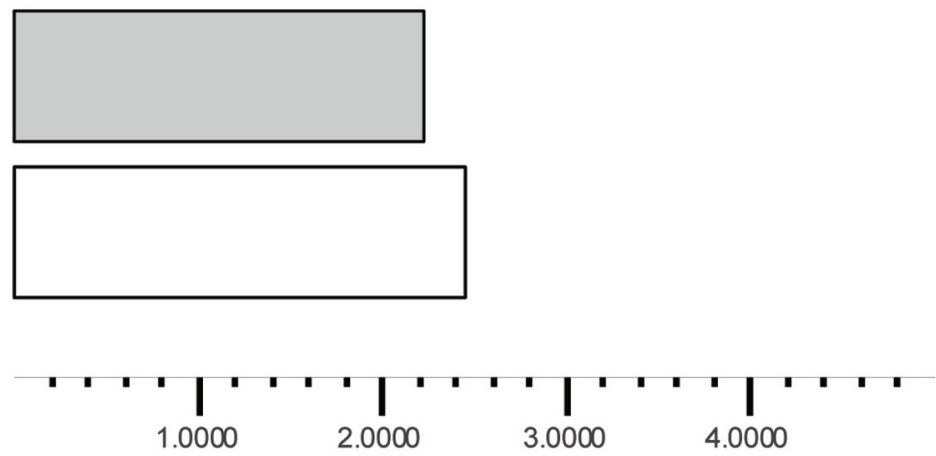

\section{1=Poor, 3=Ave rage, $5=$ Excellent}

were significant differences over number of reporters $(F=5.9, d f=6,366$, $p<.001$ ) with TV journalists more happy with this than all other journalists, and weekly national newspaper journalists least happy (eta=0.08). Radio journalists were also significantly more concerned than TV journalists about lack of senior staff (eta=0.02) and pay (eta=0.05). While the concern about pay is not perhaps surprising, the level of concern is significant. Likewise, the level of concern about mentoring and training is worrying, in an industry with such a high proportion of younger, less experienced reporters. 
act ethically (Graph 4). They generally agree that the media should provide analysis of important issues, are free to tell the truth, make decisions based on journalistic values, and that the media is performing its watchdog role. They do not want more regulation to bring in higher standards, or a return to the traditional role of newspapers being vehicles of record. That said, there were some statistically significant variations in opinion by gender, job, and age. Women and men were broadly in agreement on ethical issues. The only significant difference of opinion was that women were neutral on the need for more regulation to bring in higher standards, whereas men disagreed with this $(t=-3.9, d f=2,381, p<.001)$.

Subeditors in general appeared to take a more conservative stance on ethical issues, agreeing, for example that the New Zealand news media needs

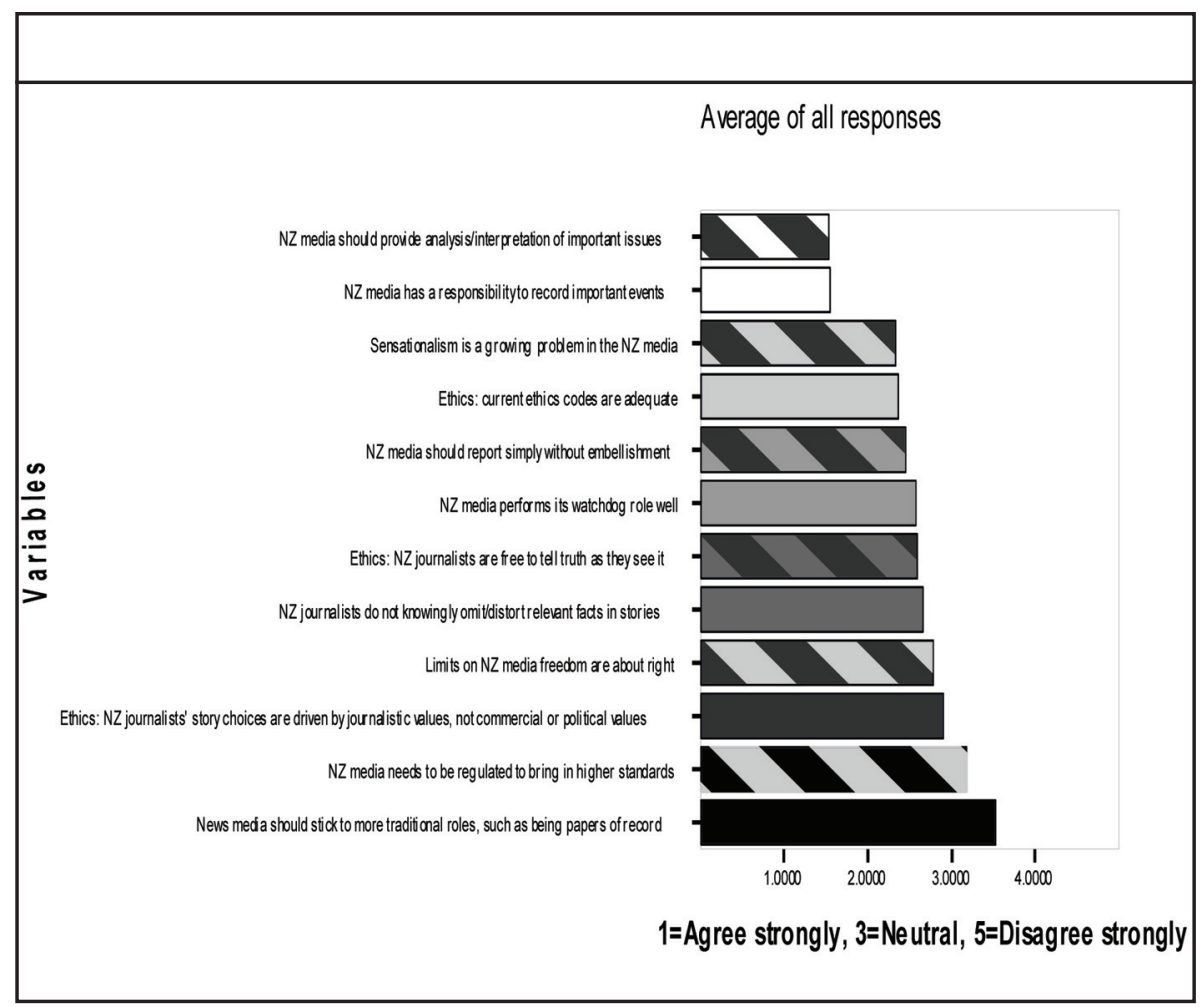


to be regulated to bring in higher standards, while reporters disagreed, and management disagreed more strongly $(F=16, d f=2,398, p<0.01)$.

While reporters and managers agreed that story choices were driven by journalistic values, rather than commercial or political values, subeditors disagreed slightly with this statement $(F=5, d f=2,391, p<.007)$. When analysed by employer, national magazine journalists were also more likely to think story choices were driven by commercial or political values than their national daily newspaper counterparts (eta=0.03, $M=3.4$ v $M=2.7, S D=1$ ).

On a question testing the water for future research, 65 per cent of respondents $(n=441)$ agreed that 'sensationalism' was a growing problem in New Zealand news media - 22 per cent agreed strongly with the proposition. Given the opportunity to ascribe the characteristics of sensationalism, respondents $(n=320)$ came up with a variety of description ranging from 'emotive language, exaggeration, shallow research, selective emphasis' to 'over dramatisation of simple facts or human situations, bloated headlines, melodramatic language that overstates the facts or circumstances, bending of angles or perspective to the degree that distorts the proper story'.

A significant number of respondents reported having been plagiarised, the responses highlighting theft of their work by journalists working in all areas of the news media, including television, radio, print and the internet: 48 percent said they had had their work stolen by print journalists; 40 percent by internet practitioners; 36 percent by radio; and 28 percent by television. Significantly, 35 percent, $(n=149)$ considered plagiarism a growing problem. Asked for their perceptions of the reasons for a growth in the practice, respondents came up with a variety of issues ranging from a believed high percentage of inexperienced journalists in under-resourced workforces, to a perceived practice of small community radio stations taking shortcuts by simply reading copy from their local newspaper. The responses also signalled a large degree of disquiet about the ease of 'cutting and pasting' from the internet. The responses need to be kept in perspective - a majority of journalists surveyed say they have never been plagiarised and do not believe it to be a growing problem. Nevertheless, the strength of feeling indicated in the responses - 'lack of moral fibre by journalists', 'internet is terrible at ripping off copy'-recommends further research.

\section{Commercial pressures and media freedom}

More than half of those that answered this question (55 percent, $n=213$ )

186 PACIFIC JOURNALISM REVIEW 13 (2) 2007 
agreed that newsrooms had been pressured to do a story because it related to an advertiser, owner, or sponsor. A third (33 percent, $n=127$ ) said no, while 11 percent $(n=51)$ did not know. There were significant differences by employer $\left(x^{2}=64, d f=26, p<0.001\right)$, with those in TV and radio more likely to say no, while higher than expected numbers of national newspaper, regional newspaper and magazine, and regional broadcast journalists said yes. More than two thirds of all journalists (67 percent, $n=268$ ) thought commercial pressures were hurting the way news organisations do things, while a quarter (27 percent, $n=106$ ) thought they were either simply changing things or having no effect. The level of concern about commercial pressure is slightly higher than the 61 percent reported in 2004 in the US Pew survey of US journalists (Pew, 2007). ${ }^{4}$ All generally agreed that limits on media freedom are about right.

\section{Freelancers/voluntary/part-time}

Despite anecdotal evidence of concern about pay, this group scored it as slightly above average. Dissatisfaction with the way their work is edited, and the feedback they get, were more significant concerns. However, the small sample size of this group $(n=10)$ means these results should be interpreted with caution. Further work is needed on this much-under surveyed group.

\section{Political views}

The watchdog role of journalists

This question asked those who thought the media was not doing its watchdog role well, what they thought should be done about it (Graph 5). A thematic analysis of explanations $(n=111)$ made it clear that by far and away the most frequent concern related to resourcing. Simply put, most respondents indicated that the watchdog role could not be performed without more journalists on staff, more time allocated to pursue investigations, and more pay to attract and retain experienced journalists both to perform investigations and to mentor newer staff into the investigative role. The next most common theme (although only mentioned a third as many times as resourcing) related to the need for more analysis; stories needed to be more complex, and editors needed to be willing to encourage and support publication of indepth treatments of issues as well as just expecting a churn of daily news: 'Anything that's complicated is often too difficult for newsroom managers, who need 


\section{Graph 5: Political views}

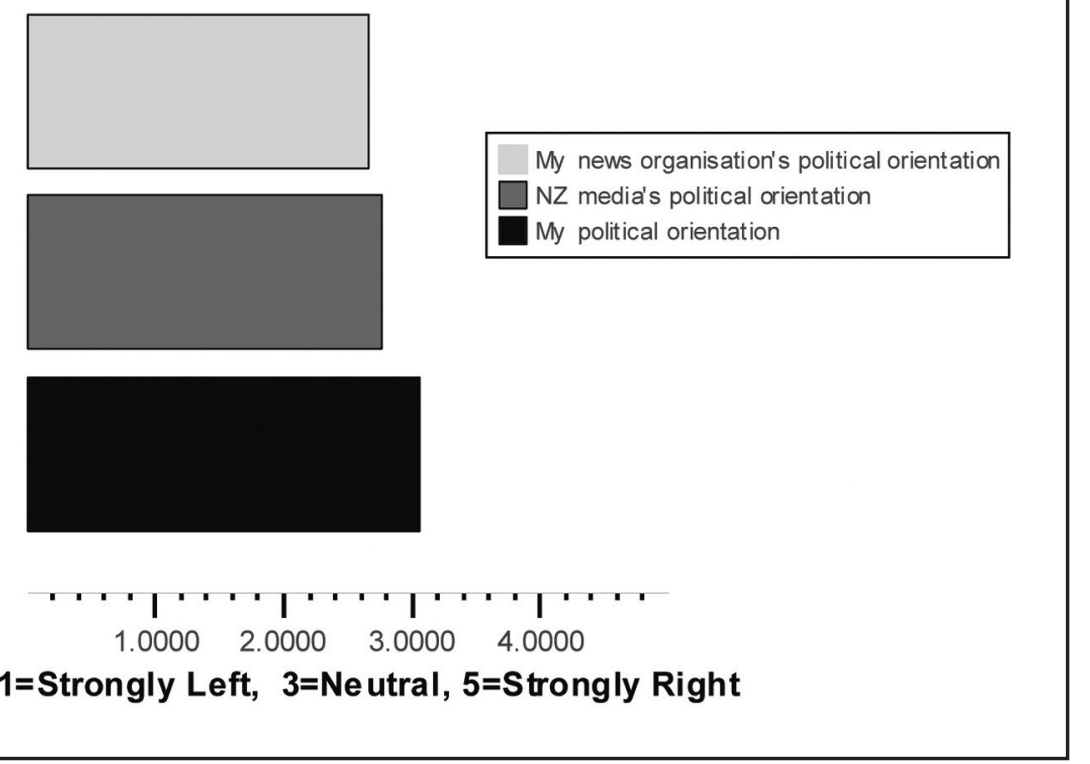

staff to deliver now, and now and now. Half a dozen average, easily compiled stories are seen as better than one time consuming or technical one, not easily understood by the average reader.'

The other themes in decreasing order of frequency were: that journalists need more skill in investigation; that regulatory changes are needed to privacy laws, reporting of suicide, access to court information, among others, to enable investigations; that newsrooms and editors must actively encourage a proactive investigative 'digging' stance among journalists, rather than waiting for crises to prompt investigation; that the morphing of news into entertainment, especially in broadcast, is an issue; that advertisers and owners can and do influence the media's ability to be a watchdog; that codes of ethics and standards need to be revisited, redesigned, and better enforced; that public relations is a barrier: '[We need] more of us ... we are always outnumbered by PR companies and ... press secretaries.' Lastly, themes mentioned that training does not adequately instil investigative skills or mindsets and that poor pay and conditions for journalists discourage the adoption of a watchdog stance. 


\section{Attitudes to public relations}

The open question 'What do you think of public relations?' was designed to sample the widest possible spectrum of journalists' attitudes towards public relations by giving no indication of any expected direction or nature of response. No word limit was placed on the response box. Of the 514 people who responded to the survey, 354 (68 percent) answered this question. Responses ranged from one word to 225 words, with average length 22.6 words. This relatively short response length suggests we collected what we were hoping for - short, pithy, associative 'gut reactions' to the stimulus 'public relations'.

A thematic analysis using a qualitative, grounded theory methodology (Glaser, 1992), showed responses were fairly evenly-split into two main categories. More than half took a stance emphatically for or against public relations. In the most positive comments, which slightly outnumbered the negative comments, public relations was considered a crucial, often misunderstood, function in society, useful for story ideas, access to interviewees, background facts, and statistics. In less enthusiastic but still positive comments, public relations was seen as 'A necessary voice-piece that represents an organisation or person, but it is not the only voice out there, nor is it the strongest'. In the most negative comments, public relations was considered wholly wrong or evil, with invective such as 'loathsome', 'paid liars', 'pernicious', and 'peopled by sell-out scum' typical. Other negative comments were more moderate, although still opposed to public relations, seeing it for example as "another obstacle to be overcome by news organisations" or as an annoyance.

Contrasting with the clear groups of comments for and against public relations, around one-fifth of the comments were inherently equivocal, seeing the industry as too complex and diverse to be summed up easily, as having intertwined good and bad aspects, or as differing depending what client or organisation was represented. The greatest number of these ambivalent comments suggested that there exist two dichotomous types of public relations practitioner: 'They can either be very helpful for getting at sources or they can be a painful barrier between the real issue and the journalist.' This 'equivocal' code also contained the single most common verbatim repeated phrase in the corpus of comments: 'necessary evil'. This phrase encapsulated the ambivalence many respondents felt towards public relations: as one said: 'It's a love/hate relationship. As much as it pains me to say it, they are needed'. 
The remaining comments, just under one-third, made specific observations or raised particular issues of concern, including that: public relations practitioners enjoy better pay and conditions than journalists; public relations practitioners lack media understanding or skill; journalists are responsible for, but sometimes insufficiently skilled in, dealing appropriately with public relations material; increasing commercial pressures on journalism increase public relations' influence; public relations is taking skilled people from journalism; and the boundaries between public relations and journalism are problematically blurring. All of these issues will be followed up in further research.

\section{What do journalists want to know more about?}

The final question in this survey asked if there any important questions missing from the survey. Responses demonstrated a vibrant curiosity about and interest in the state of journalism in New Zealand. Many wanted to know more about topics raised in the survey, or the reasons for what they saw as trends, such as low pay, ethics and standards, corporate influence, and the overall media climate. In a theme analysis that endeavoured to detect overall patterns, the two most frequent areas of comment related to motivation and recruitment issues, and pay and conditions. More than anything else, respondents wanted us to ask them why they became a journalist, why they stayed in the job, whether they were happy and why, and whether they were planning to 'get out' and if so why or why not. Many felt the answers to these questions could help build insight into ways the profession could attract and retain skilled staff, and several offered very positive reasons why they greatly enjoyed their journalism career. Comments that we should have asked for more detail about pay and conditions were almost as numerous, with suggestions such as '[ask] why newspapers have such a high turnover of staff, because the hours are long and the pay ridiculously low' frequently indicating a connection between pay and conditions and the most frequently-nominated issue of motivation and retention. Respondents requested opportunities to talk about issues such as hours of work, sick leave, work-life balance, the quantity of work required during a shift, and support for professional development.

The two next most-nominated themes, relating to quality issues and training, were raised only about half as often as the first two themes, indicating that recruitment, retention, pay, and conditions are the stand-out concerns. Respondents said we should have asked questions about whether NZ media

190 PACIFIC JOURNALISM REVIEW 13 (2) 2007 
quality was declining, different from overseas media, and why. We should have asked 'Does the media do a good job?' in a variety of ways. It was also suggested we should also have provided more opportunity to comment on the quality and relevance of training.

Respondents also wanted us to ask questions about (in decreasing order of frequency): the impact of ownership, especially overseas ownership ('From my 30-odd years in journalism it now appears that the news is money-driven ... the return on shareholders' funds has now become uppermost in the metropolitan newspapers owned by overseas corporations, to the detriment of coverage.'), on media quality and journalists' conditions; whether skill levels are declining and if so why (most suggested they were declining significantly); what impact media trends such as convergence and new technologies are having now and will have on the industry in future; influence or independence issues such as whether some media are biased or whether they personally have experienced pressure to slant a story; ('Have you ever shaped a story to fit in with your editor's political bias or personal interests to enhance your standing in the newsroom and gain future promotion and pay rises?' 'Has your organisation put pressure on you not to write a story, or to change a story, because it has implications for an advertiser? For me the answer is yes, and it felt terrible.')

Less frequently, management and newsroom culture and communication issues such as whether managers are actually qualified to manage ('Why are some newspaper managers so utterly out of touch with modern management techniques geared for inclusion, teamwork, loyalty, innovation and motivation?' 'Why is there no management, team training in newsrooms or structured succession planning? Why is there limited feedback given to reporters to improve their skills?') Next, whether newsrooms are 'healthy' places to work ('Are junior journalists exploited and abused? Do reporters in your newsroom get bullied?'), diversity issues related both to the make-up of the media and the stories covered; the transition from training to industry; the role of adjunct bodies such as professional organisations, media watchdog bodies, and unions (are they needed, are their roles changing, are they effective?); more specific questions about ethics than the ones we posed, such as how other journalists cope with the pressure to sensationalise stories ('It is quite different to the neutral stance taught at journo school') and a range of 'other' areas including specific questions about freelancers, public perceptions of the media, regulation, and the role of media commentators. 
The public perception of the media was of interest to several: 'Is the public's negative perception of the media fair?' asked one. 'Why is the great NZ public so unappreciative of getting generally good and comprehensive ... national news service ... at very little cost?' asked another. The poor pay and conditions of freelancers was a common theme; particularly if it affects women more than men. Some wanted to know which newspapers other journalists read, whether there was enough specialist writing in NZ, and the quality of writing overall. One wanted a way of rating different news outlets on their quality of coverage.

Some thought the survey overall poor, others thought it worthwhile. Not all felt the oft-discussed fears about declining standards and commercial pressures were justified: 'It is way better than it was when I started in journalism in the sixties ... much greater range in subject matter being covered, much better coverage of politics and analysis, and much more racial inclusiveness - though there is still a way to go on this last.' A number wanted to know more about why journalists found the work satisfying: 'Do we do it for love or money? Excitement and adventure, variety and the pleasure of doing the job well, and the enjoyment of seeing my work in print-even after years of doing it. Lucky to do a job I like.' 'I love what I do, the challenge ... makes the job incredibly satisfying.' 'Bring me the people! Bring me the stories! Bring me the excitement of seeing my words and name in print! It's the best job I've ever had. I finally feel like I've got a purpose.'

\section{The future of journalism in New Zealand}

As with other major institutions and professional practices in the Western society, journalism is facing unprecedented challenges and uncertainties. This 2007 survey has focused on those working within the formal parameters of 'journalism', that is, largely employed by media institutions with wellestablished processes for gathering and disseminating news and opinion.

This survey has also concentrated its attention on journalism-as-we-know it; it has paid less attention to journalism-as-it-might-become, even though the journalists in this survey were able to comment on the impact of new technology in the newsroom. Opinions were mixed as to whether the New Zealand media was keeping up with changing technology, as in the following comments: 
Slowly we are edging ahead - not as swiftly as overseas organisation but at a pace in step with the other key players in this country.

Slowly - the use of internet sites for breaking news stories is still a work in progress.

Yes-we are slowly catching up. I think our news websites are becoming more quality and are being utilised more often.

Balanced against this general optimism about the incorporation of new technology into journalistic practice were a number of bleaker assessments or experiences,

We have one printer to share in our entire newsroom, including features, sports, subs, news and senior news staff. It broke down a few weeks ago and it took 2-3 weeks to replace it.

Many newsrooms use decade-old software.

Use of internet resources is still looked on with fear.

A summary comment about the changing technological landscape could possibly be the following:

There's a growing awareness. However a true understanding of the internet, for example, and its impact of society, on business, education, and culture is still generally not appreciated or understood. There are still only a dozen or so people in this country who can write authoritatively beyond the hype of gadgets and gizmos and entertainment distractions, to comment on the wider picture.

Technological changes - most significantly, the accelerating shift towards a digital world - has produced a wave of phenomena such as blogging, citizen journalism, internet social networking and alternative publishing. The traditional means of news production and distribution are now under threat and, to date, the primary response has been to either produce complementary material (such as newspaper websites), or to carry on regardless. No one has a special option on accurately predicting the future, but as the current 
journalists want to see change, and also provides insights for those calling for more diversified newsrooms. These are not just the predictable and contentious areas such as more pay, staff and equipment. While some caution must be exercised in extrapolating from this sample, it seems reasonable to conclude that improvements in mentoring, training, and support, as well as more opportunity for discussion and input into ethical and professional issues such as sensationalism, and coping with commercial and advertising pressures, would be well-received by a majority of New Zealand journalists.

\section{Notes}

1. Comparison with Census/other surveys - see Graphs 6 and 7. For these graphs, other categories such as photographers etc were excluded.

2. This figure is an average of the 66 percent national and 57 percent local US figures.

3. Analysis: Variables were tested across gender, age, job status and employer. To attain suitable sample size, job status was divided into three categories: reporter, subeditor, and manager, of full-time employees only. In this case, manager included all categories from chief reporter/chief subeditor level up through deputy editor, editor, general manager and publisher. Likewise, to attain suitable sample size, employer

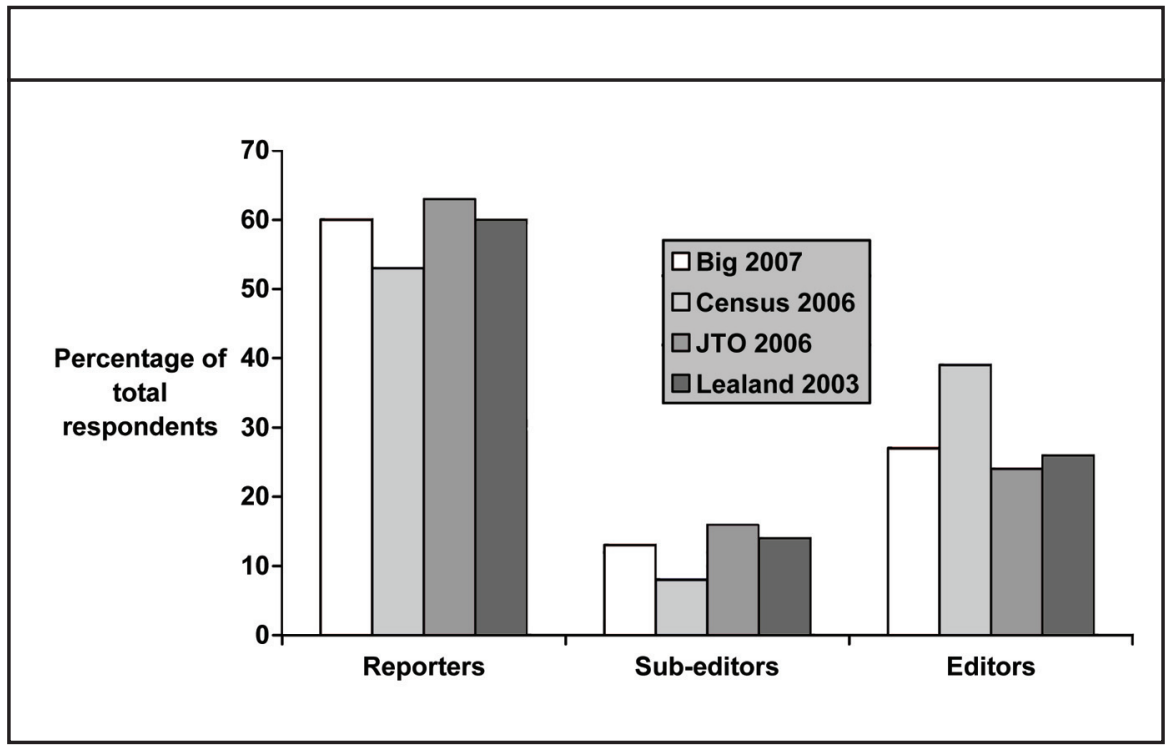




\section{Graph 7: NZ journalists: key indicators}

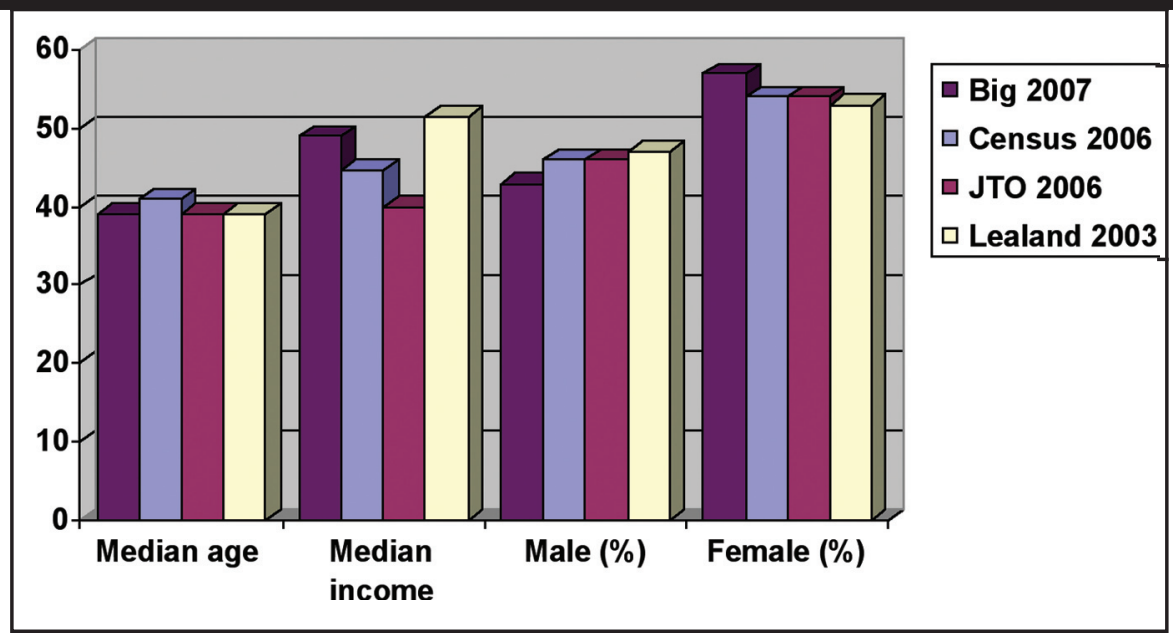

was recoded into meaningful sample sizes. Only meaningful differences across these variables are reported. For example, when females agreed to a statement and males did not, rather than slight shades of difference when both groups agreed. Apparently meaningful differences were tested for significance using independent-samples $\mathrm{T}$ test, Chi-Square or Anova tests where appropriate. Post-hoc comparisons were conducted on Anova data where appropriate, using the Tukey HSD test.

4. The approximate median age and income were derived using the formula below. As the data were only available in bands, only approximate median age and income could be calculated. The approximate median was preferred to calculations of approximate average as median is considered a more reliable indicator of the central tendency for data such as salary bands and age, which can be skewed by significant outliers (Meyer, 2002). This tendency was confirmed by the fact that an initial calculation of approximate average income was tested and found to produce a result significantly at variance to the median. For the calculations of approximate median, those who did not state income were omitted, as were those who did not state ethnicity. Likewise, those who specified more than one ethnic group were omitted from the charts shown, although the complete dataset is included at the end of this article. To calculate the approximate median age and income, the following formula was used (Jeffcoat, 1998):

$\mathrm{m}=\mathrm{aM}+\mathrm{n} / 2-\mathrm{gM} \times \mathrm{wM}$

\section{$\mathrm{fM}$}

where $\mathrm{aM}=$ lower limit of median class

$\mathrm{gM}=$ number of values below median class

$\mathrm{fM}=$ frequency of median class

$\mathrm{wM}=$ width of median class. 
5. It is noted, however, that there were numerous comments on the wording of the question relating to overall orientation in the open comment section, and that many people felt some media had different political orientations than others, making it difficult to perceive an overall tendency.

\section{References}

Glaser, B. (1992). Basics of grounded theory analysis. California: Sociology.

Henningham, J. (1995). A national survey of New Zealand journalists. Australian Studies in Journalism, 4: 296-298.

Hollings, J. (2007). Still European and female, but older: profiling the New Zealand journalist. Pacific Journalism Review 13(1): 183-193

Jeffcoat, C., Belgrave, P. (1998). You can probably manage business statistics. Roseville: McGraw-Hill Book Company.

Lealand, G. (1988). A national survey of New Zealand journalists 1987. A report for the New Zealand Journalists Training Organisation. Wellington: NZJTO

Lealand, G. (1994). A national survey of New Zealand journalists 1994. A report for the New Zealand Journalists Training Organisation. Wellington: NZJTO

Lealand, G. (2004). Still young and female: a (modest) survey of New Zealand journalists. Pacific Journalism Review . 10(2): 173-196

Lloyd, J. (2007, September 14). When the left wasn't right any more, The Guardian Weekly, p. 35

Meyer, P. (2002). Precision journalism: a reporter's introduction to social science methods ( $4^{\text {th }} \mathrm{Ed}$.). Lanham: Rowman \& Littlefield.

New Zealand Journalists Training Organisation. (2006). National survey of journalists 2006. Retrieved 12 September 2007 from: www.journalismtraining.co.nz/surveys. html

Statistics New Zealand. (2007). Census of population and dwellings statistics

Strong, C., Hannis, G. (2007). The visibility of female journalists at Australian and New Zealand newspapers: the good news and the bad news. Australian Journalism Review, 29(1): 115-125.

The Pew Research Center for the People and the Press (2004): Bottom line pressures now hurting coverage, say journalists. Retrieved on 12 September 2007 from: http://people-press.org/reports/display.php3?ReportID=214

Weaver, D. \& G. Cleveland Wilhoit (1998). Journalists in the United States. In Weaver, The Global Journalist: News People Around the World. New Jersey: Hampton Press, pp. 395-414.

James Hollings and Alan Samson are lecturers in journalism at Massey University, Wellington. Elspeth Tilley is a lecturer in communication at Massey University, Wellington. Geoff Lealand is associate professor of screen and media studies at the University of Waikato. The authors would like to thank Grant Hannis, Karl Pajo, David Robie, Frank Sligo and Cathy Strong for their 
j.h.hollings@massey.ac.nz, lealand@waikato.ac.nz, a.m.samson@massey.ac.nz, e.tilley@massey.ac.nz

\begin{tabular}{|c|c|c|c|c|}
\hline & Job & Frequency & Percent & $\begin{array}{l}\text { Valid } \\
\text { percent }\end{array}$ \\
\hline \multirow[t]{11}{*}{ Valid } & Reporter full time & 219 & 42.6 & 43.9 \\
\hline & Subeditor full time & 43 & 8.4 & 8.6 \\
\hline & Photographer full time & 18 & 3.5 & 3.6 \\
\hline & Newsroom middle manager full time & 118 & 23.0 & 23.6 \\
\hline & General manger/publisher full time & 11 & 2.1 & 2.2 \\
\hline & Newsreader full time & 1 & .2 & .2 \\
\hline & Reporter part time/freelance & 56 & 10.9 & 11.2 \\
\hline & Subeditor part time & 4 & .8 & .8 \\
\hline & $\begin{array}{l}\text { Newsroom middle manager part } \\
\text { time/freelance }\end{array}$ & 11 & 2.1 & 2.2 \\
\hline & General manager/publisher part time & 3 & .6 & .6 \\
\hline & Missing & 30 & 5.8 & \\
\hline \multirow[t]{2}{*}{ Total } & & 514 & 100.0 & \\
\hline & Employer & Frequency & Percent & $\begin{array}{l}\text { Valid } \\
\text { Percent }\end{array}$ \\
\hline \multirow[t]{10}{*}{ Valid } & TV & 45 & 8.8 & 9.1 \\
\hline & Radio & 45 & 8.8 & 9.1 \\
\hline & Newspaper daily national & 105 & 20.4 & 21.3 \\
\hline & $\begin{array}{l}\text { Newspaper daily regional or under } \\
25,000 \text { circulation }\end{array}$ & 63 & 12.3 & 12.8 \\
\hline & Magazine national & 38 & 7.4 & 7.7 \\
\hline & $\begin{array}{l}\text { Magazine regional or under } 25,000 \\
\text { circulation }\end{array}$ & 20 & 3.9 & 4.1 \\
\hline & News agency & 11 & 2.1 & 2.2 \\
\hline & Online publication & 6 & 1.1 & 1.2 \\
\hline & Self & 10 & 1.9 & 2.0 \\
\hline & Missing & 21 & 4.1 & \\
\hline Total & & 514 & 100.0 & \\
\hline
\end{tabular}


Copyright of Pacific Journalism Review is the property of Auckland University of Technology and its content may not be copied or emailed to multiple sites or posted to a listserv without the copyright holder's express written permission. However, users may print, download, or email articles for individual use. http://www.aut.ac.nz/depts/commstud/journ/pjrsubs.shtml 